\title{
Bird diversity in transition zone of Taka Bonerate, Kepulauan Selayar Biosphere Reserve, Indonesia
}

\author{
RADISTI A. PRAPTIWI $I^{1,2, \vartheta}$, RONNA SAAB ${ }^{1,3}$, TATANG MITRA SETIA ${ }^{1,3,4}$, GUSTI WICAKSONO $^{1}$, \\ PRAWESTI WULANDARI ${ }^{1}$, JITO SUGARDJITO ${ }^{1, v v}$ \\ ${ }^{1}$ Centre for Sustainable Energy and Resources Management, Universitas Nasional. J1. Sawo Manila 61, Pejaten, Jakarta Selatan 12540, Jakarta, \\ Indonesia. Tel. +62-21-78848152, `email: radisti_ayu@outlook.com, ” "email: sugar@unas.ac.id. \\ ${ }^{2}$ Department of Biotechnology, Universitas Esa Unggul. Jl. Arjuna Utara No. 9, Jakarta Barat 11510, Jakarta, Indonesia. \\ ${ }^{3}$ Department of Biology, Graduate School, Universitas Nasional. Jl. RM Harsono No. 11, Ragunan, Jakarta Selatan 12550, Jakarta, Indonesia. \\ ${ }^{4}$ Faculty of Biology, Universitas Nasional. J1. Sawo Manila 61, Pejaten, Jakarta, Indonesia.
}

Manuscript received: 8 November 2018. Revision accepted: 25 February 2019.

\begin{abstract}
Praptiwi RA, Saab R, Setia TM, Wicaksono G, Wulandari P, Sugardjito J. 2019. Bird diversity in transition zone of Taka Bonerate, Kepulauan Selayar Biosphere Reserve, Indonesia. Biodiversitas 20: 820-824. Conservation management in the buffer and transition zones of Biosphere Reserves play an important role in ensuring enhanced core zone protection. Tambolongan and Polassi are two islands located in the administrative region of South Sulawesi, Indonesia, and part of the transition zone area of UNESCO's Taka Bonerate-Kepulauan Selayar (TBKS) Biosphere Reserve (BR). These two islands can be considered as some of the most populated islands in the region, containing a variety of human activities. These human activities, such as the ever expanding agriculture and the building of human habitation have put pressures toward ecosystem and species conservation in the BR. Bird are often the focus of conservation efforts, due to their roles in supporting the ecological functioning of their habitats. This study aims to provide baseline data of bird diversity in Tambolongan and Polassi that can be used as a proxy indicator of ecosystem health and input to conservation strategies within the BR area. A Visual Encounter Survey (VES) method is used to examine bird diversity index. Results from the observation recorded a total of 29 species were found in both islands, with 5 listed as protected species and 3 categorized as migratory species. The comparison between the two islands showed that the bird diversity index (H') differs only slightly ( $\mathrm{H}^{\prime}$ 'Tambolongan=2.98; H'Polassi=2.71). This study provided the initial attempt in understanding the role of habitats or land cover types, guild types and human interferences in determining the diversity of bird population - and related ecosystem health - in the area. Such knowledge is essential in providing the information necessary for sustainable management practices. This work represents the first study to inventorize avian species diversity in the transition zone of TBKS BR.
\end{abstract}

Keywords: Birds, biosphere reserve, diversity, transition zone

\section{INTRODUCTION}

Indonesia is one of the countries known as one of the biodiversity hotspots area in the world (Mittermeier 1998, Marchese 2015). Most species of wild animals still reside in forested areas, estimated to be around more than $50 \%$ of the land available in the country (Alisjahbana and Busch 2017). These areas are also home to a significant number of birds - key species in the functioning of many ecosystems. The Wallacea area, of a particular interest to bird diversity research, supports a large number of endemic bird species in the region and includes the islands of Sulawesi (where the study was performed), Lesser Sunda and Mollucas. Despite the growing number of observation discovering new species in the biodiversity hotspots of Indonesia, such areas face gradual diminishing of habitat size due land conversion to various other uses deemed more economically profitable, for instance agricultural activities and the development of residential areas (Brooks et al. 2002).

Birds as one of the most visible residents of the threatened areas hold a key role in the functioning of the ecosystem. They perform services essential for the regulation of ecosystem health, such as seeds dispersal, pollination of tropical plants and pest control (Philpott et al. 2009, Sekercioglu 2012). When birds ingest fruits from fruit bearing trees, they would leave the seeds undigested, excreting them instead to the ground, leaving them ready for germination. Birds that consume pollen from flowering plants would carry with them pollens, transporting and inadvertently distributing the pollens into nearby flowers, causing them to be pollinated. While carnivorous birds that hunt and prey on small animals, such as rodents, would keep the population of the vermin under control, leaving the food chain structures balanced through this act of predation.

The birds inhabiting some of the islands of Indonesian archipelago have been observed to reside in some areas in two different types of habitats, the forest and agricultural land (Waltert et al. 2004, 2005). The forest habitats are under pressure from the aforementioned land use change factors (Sodhi et al. 2005). These pressure on bird habitat also put the birds at risk, as the reduction of forest cover may lead to the reduction of the chance that the bird can obtain its livelihood. However, the availability of forest patches in the land changed to agricultural uses have been 
observed to still maintain adequate level of support for the existing bird species in the area (Waltert et al. 2004, 2005).

Birds may also function as a proxy indicator of the ecosystem health. Measurement of indicators such as bird diversity and guilds, structure community, population density and abundance can point out the extent of disturbances in their habitat (O'Connell et al. 2000, Tanalgo et al. 2015). Moreover, it has been observed that the species richness and composition of the birds are important parameters of a stable and functioning ecosystem (Bibi and Ali 2013). Indeed, with the growing interests on the management of ecosystem and its services, measurement of diversity and abundance of birds have been used as indicators of the quality of ecosystem services in a given area, especially as the roles they perform in the ecosystem, such as seed dispersers and predators, have been claimed to underpin the ecological functions which form the base of ecosystem services (Andersson et al. 2007).

Considering the aforementioned factors, this paper aims to report the results of a study performed in Tambolongan and Polassi islands, South Sulawesi, that carried out measurement of bird species diversity and their guilds, linked with observation of their current habitat (land cover types). This study provides baseline data that can be used as an initial assessment towards a more thorough investigation of factors needed in a conservation management strategy in the area. Indeed, the use of bird diversity data to evaluate and prepare an ecosystem or conservation management plan has been demonstrated in other studies (Mas and Dietsch 2004). In addition, this study also serves as the first study inventorying bird species in Tambolongan and Polassi, South Sulawesi, Indonesia.

\section{MATERIALS AND METHODS}

\section{Study area}

Field observation was conducted in the month of June 2018, and took place in two islands situated in the transition zone of Taka Bonerate Kepulauan Selayar (TBKS) Biosphere Reserve (BR), those are: Tambolongan Island (6.6188 $\left.{ }^{\circ} \mathrm{S}, 120.4098^{\circ} \mathrm{E}\right)$ and Polassi Island (6.6741 $\left.{ }^{\circ} \mathrm{S}, 120.4380{ }^{\circ} \mathrm{E}\right)$. Both islands are located in Selayar Regency, South Sulawesi, Indonesia (Figure 1). The area is a part of the designated UNESCO Biosphere Reserve site, where a combination exists between the sustainable uses of the area by human that are aligned with the conservation needs to ensure that both human and nature could thrive without jeopardizing the well-being of the other. However, despite the status of the area, comprehensive monitoring regimes that provide information for its management strategies are currently still unavailable.
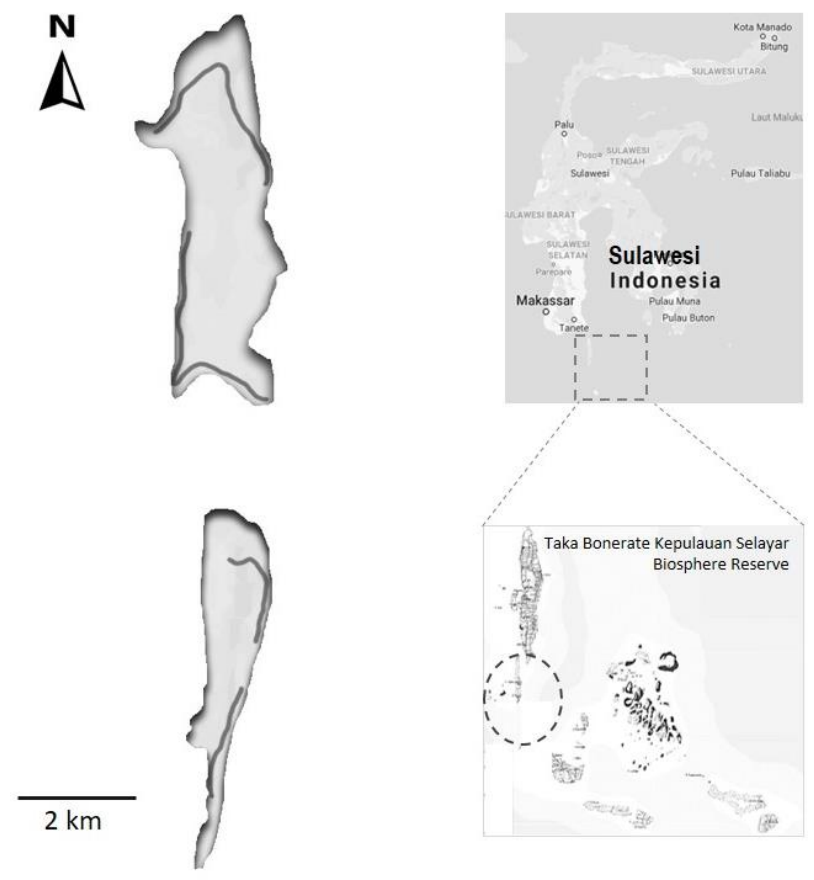

Figure 1. Sampling location and pathways (represented as grey lines) in Tambolongan (the upper island) and Polassi (the lower island), Selayar Regency, South Sulawesi, Indonesia

\section{Procedures}

Observation was conducted in two islands (Tambolongan and Polassi) for each sampling visitation. A visual encounter method (VES) was used to inventorize bird species along specified observation pathways as illustrated with grey lines in figure 1. Observation pathways were selected to represent variation of terrestrial habitats on each island. Data collected for each encountered species were recorded according to local name, observation time and location, and numbers observed. In addition, photograph of each species was collected for further identification and scientific name labelling.

\section{Data analysis}

Bird species identification was performed using a reference book (van Ballen et al. 2016). The diversity index was measured using Shannon-Wiener ( $\mathrm{H}^{\prime}$ index) calculation (Spellerberg and Fedor 2003). The H' index assumes that the random sampling of each species observed sufficiently represents the majority of species in its habitat (Bibi and Ali 2013). The species richness (D index) was calculated using Menhinick index (Menhinick 1964). The evenness index for each sampling location was measured using Pielou (J') index (Pielou 1966). The evenness index is used to indicate the relative abundance of different species and evaluate the evenness of distribution among existing species (Bibi and Ali 2013). These indices have been commonly used in studies analyzing the diversity of birds and other species found living in different types of habitats and provide means to evaluate indirectly the ecosystem health (Cooleman et al. 2015; Li et al. 2017; Tanner et al. 2017; Dinesh et al. 2018; Mentil et al. 2018). 


\section{RESULTS AND DISCUSSION}

Tambolongan and Polassi islands are situated southward of Sulawesi Island, Indonesia, and are parts of transition zone of Taka Bonerate Kepulauan Selayar (TBKS) biosphere reserve. Each island measures approximately $9.8 \mathrm{~km}^{2}$ for Tambolongan and $3.3 \mathrm{~km}^{2}$ for Polassi. Despite their relatively remote location and small terrestrial area size, each islands are home to about 1300 human inhabitants. In the past decade, the islands have seen an increase of human population of up to $20 \%$ (Indonesian Bureau of Statistics 2017). The population growth indicates that appropriate environmental management plan is necessary to ensure that it would not put pressure towards the ecosystem health in both islands.

As observed in the field studies performed in these islands, both have experienced some degree of environmental pressures. One of the most apparent of these pressures is the destruction of marine habitats (coral reefs) in the area due to unsustainable fishing practices, such as the use of bombs and tranquilizers. The destruction is mainly the result of the lack of alternatives for the human population in the islands in earning their livelihoods. Nonetheless, recent trends have seen growing number of local population converting to land based livelihoods, mainly from agricultures. This shift has actually resulted in the conversion of previously pristine habitats in the islands into fields, used for more economically productive purposes. It is thus may be deemed important to monitor environmental health in the area to prevent the situation from escalating unsustainably.

One of the key indicators of environmental pressures is bird diversity. Birds often perform key roles in the functioning of their ecosystem habitats, such as seed dispersal and predation of pest (Philpott et al. 2009, Sekercioglu 2012). As such, measurement of indexes related to bird species existing in the areas can provide information on the state of ecosystem health to ensure that local management of resources can be performed sustainably. Based on this consideration, this study surveyed the types of birds that can be found in each island and attempted the analysis of their community structures.

Field sampling showed that there were a total of 29 bird species from 21 family found in the two islands (Table 1). Out of the 29 species observed, 3 species were identified as migratory birds, those are: Charadrius alexandrines, Charadrius peronei and Numenius phaeopus. In addition to this, 5 bird species are listed as protected species under ministerial decree No. 92 year 2018 (published by Indonesian Ministry of Environment and Forestry), those are: N. phaeopus, Haliaeetus leucogaster, Pandion haliaetus, Megapodius reinwardt and Rhipidura Javanica. One of the protected bird species, (M. reinwardt), was observed to be occasionally hunted and consumed by the local community. Such condition has to be addressed in the environmental management strategy of the islands, for instance through public education to induce changes in public attitude by raising awareness towards the unsustainability of the practice.
Comparison of the two islands revealed that higher number of species was observed in Tambolongan (27 species) than Polassi (20 species) (Table 1). This may be attributed to its larger terrestrial area and more types of habitat. Tambolongan has at least 5 key categories of habitats, consisting of beach forest, agricultural land, savannah, mangrove forest and residential area. With the exception of mangrove forest, all other four key habitats exist in Polassi.

Although the direct measurement of the number of species seems to indicate that Tambolongan supports a more varied population of birds, the analysis of community structure indexes (diversity, richness and evenness) showed that both islands differ only slightly (Table 2). The calculation of the diversity indexes in the area revealed that Tambolongan island $\left(\mathrm{H}^{\prime}=2.98\right)$ harbors a marginally more diverse bird population than Polasi island $\left(\mathrm{H}^{\prime}=2.71\right)$. Similarly, the higher value of species richness observed for Tambolongan $(\mathrm{D}=2.46)$ than Polassi $(\mathrm{D}=2.01)$ suggests that this island supports richer types of bird. These similarities between the two islands may be attributed to their proximity that might cause birds to easily circumnavigate the distance between both islands. Such situation renders the difference between habitat sizes in the two islands may be less of an influencing factor in determining the diversity, as both islands seem capable of supporting an almost similar quality of bird community. As observed in other studies, bird diversity and richness in a similarly conditioned environment are seem to be more influenced by their guilds than by their habitat characteristics (Kim et al. 2007, Smith et al. 2018). In other words, the availability of food sources may be the key factor directly influencing the structure of the bird community.

Nonetheless, the analysis on guild types of the observed birds also show that the two islands share similar traits. As illustrated in figure 2, both islands are inhabited by birds that feed mainly on insects. The dominance of the insectivore bird population may reflect the habitat situation in both islands that have seen clearances due to conversions to agricultural lands. Despite the fact that such process removes land covers from the areas, the agricultural crops that replace them could also provide food for insects, sustaining their population (Benton et al. 2002, Smith et al. 2018). The other two feed types (seed and fish) signify the original condition of the now partially beach-forested islands with large areas of agricultural land and surrounded by sea on its sides, which supply both seeds and fish to the foraging bird population.

Table 2. Index of bird community structure in Tambolongan and Polassi.

\begin{tabular}{lccccc}
\hline Location & $\begin{array}{c}\text { No. of } \\
\text { Species }\end{array}$ & $\begin{array}{c}\text { No. of } \\
\text { Family }\end{array}$ & $\mathbf{H}^{\prime}$ & D & $\mathbf{J}^{\prime}$ \\
\hline Tambolongan & 27 & 20 & 2.98 & 2.46 & 0.90 \\
Polassi & 20 & 16 & 2.71 & 2.01 & 0.90 \\
\hline
\end{tabular}


Table 1. Diversity of birds observed in Tambolongan and Polassi, South Sulawesi, Indonesia

\begin{tabular}{|c|c|c|c|c|}
\hline Family & Species & $\begin{array}{c}\text { Island } \\
\text { Tambolongan }\end{array}$ & Polassi & No. of individuals \\
\hline Accipitridae & Haliaeetus leucogaster & + & + & 3 \\
\hline Pandionidae & Pandion haliaetus & + & - & 2 \\
\hline \multirow[t]{2}{*}{ Alcenidae } & Halcyon chloris & + & + & 6 \\
\hline & Halcyon sancta & + & - & 2 \\
\hline Apopidae & Collocalia esculenta & + & + & 19 \\
\hline \multirow[t]{3}{*}{ Ardeidae } & Ardea purpurea & + & - & 2 \\
\hline & Butorides striata & - & + & 1 \\
\hline & Egretta sacra & + & + & 5 \\
\hline Artamidae & Artamus leucorynchus & + & + & 11 \\
\hline Campephagidae & Lalage sueurii & + & + & 8 \\
\hline \multirow[t]{2}{*}{ Charadriidae } & Charadrius alexandrinus & + & - & 4 \\
\hline & Charadrius peronii & + & - & 2 \\
\hline \multirow[t]{3}{*}{ Columbidae } & Ducula aenea & + & + & 15 \\
\hline & Streptopelia chinensis & + & + & 7 \\
\hline & Treron vernans & + & + & 6 \\
\hline \multirow[t]{2}{*}{ Estrildidae } & Lonchura molucca & + & + & 8 \\
\hline & Lonchura pallida & + & + & 14 \\
\hline Hirundinidae & Hirundo tahitica & + & + & 11 \\
\hline Megapodiidae & Megapodius reinwardt & + & + & 2 \\
\hline \multirow[t]{2}{*}{ Meropidae } & Merops ornatus & + & - & 2 \\
\hline & Merops philippinus & + & - & 1 \\
\hline Muscicapidae & Cyornis rufigastra & + & + & 3 \\
\hline Nectariniidae & Cinnyris teysmanni & + & + & 18 \\
\hline Oriolidae & Oriolus chinensis & + & + & 27 \\
\hline Passeridae & Passer montanus & + & + & 14 \\
\hline Phasianidae & Coturnix chinensis & - & + & 1 \\
\hline Rhipiduridae & Rhipidura javanica & + & - & 1 \\
\hline Scolopacidae & Numenius phaeopus & + & - & 1 \\
\hline Zosteropidae & Zosterops chloris & + & + & 25 \\
\hline Total & 29 & 27 & 20 & 221 \\
\hline
\end{tabular}

Note: + : Present in the area
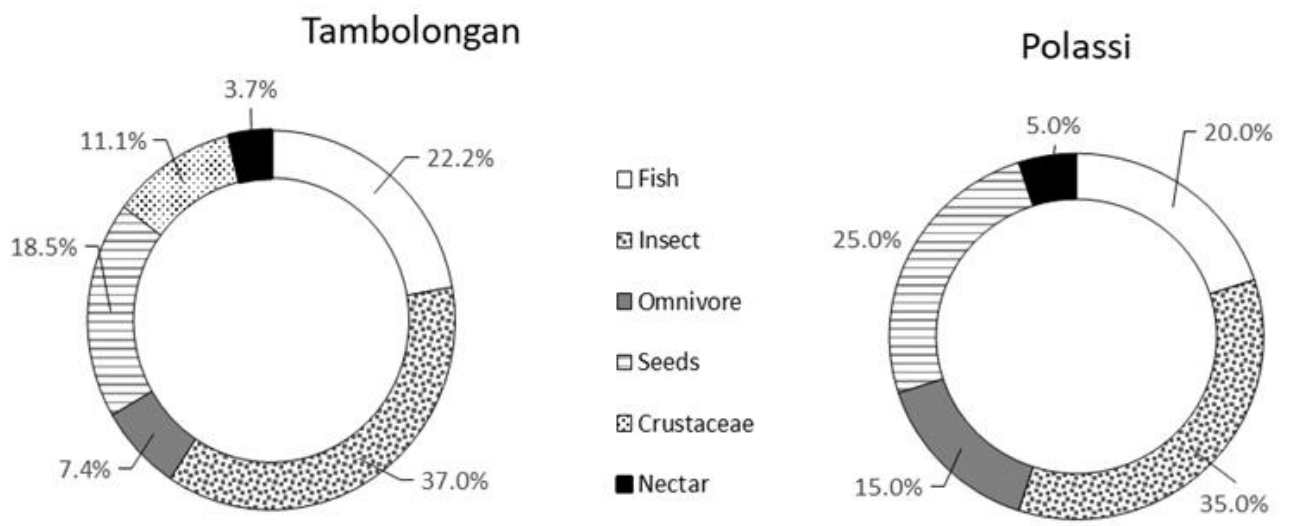

Figure 2. Percentage share of bird guild types in Tambolongan and Polassi, South Sulawesi, Indonesia

This study performed analysis on bird community structures found in the islands of Tambolongan and Polassi. It was found that both islands share similar bird community traits, as evident in the indexes calculated for the purpose of evaluating its diversity and the guilds composition. It also appears that the similarity in community traits seems to be more influenced by the guild characteristics than the sizes of the land area of both islands, which has one island (Tambolongan) measured almost three times larger than the other (Polassi). 
The present environmental conditions of the islands can be considered to experience some degree of pressures from human population growth and land conversion. However, the data discussed can be deemed to provide only the initial snapshot of ecosystem health through proxy measurement of current bird diversity condition in both islands. As such, further studies are required to ascertain whether the ecosystem health in both islands is still in good condition or already threatened by the pressures. These studies should be designed to monitor the bird population across time and to relate the indexes to various pertinent variables such as land use change, habitat types and the changes of the guild profile across time. The data collected should then be able to track changes across space and time, rendering them usable in evaluating environmental changes and their effects on ecosystem health in both islands. Such studies would act as preliminary preparation for a consistent in-situ monitoring regime, which would be needed for the appropriate management of interests between those of development and conservation, befitting the status of the site as a Biosphere Reserve. Moreover, as has been commented in another study (Yoccoz et al. 2001), the monitoring program should be supported by clear management goals that pinpoints on the way that the gathered data would be used to realize the aforementioned management objective.

\section{ACKNOWLEDGEMENTS}

This work has received funding in part from the Global Challenge Research Fund (GCRF) UK via the delivery partner Research and Innovation (UKRI) under grant agreement reference NE/P021107/1 to the Blue Communities project.

\section{REFERENCES}

Alisjahbana AS, Busch JM. 2017. Forestry, forest fires, and climate change in Indonesia. BIES 53 (2): 111-136.

Andersson E, Barthel S, Ahrné K. 2007. Measuring social - ecological dynamics behind the generation of ecosystem services. Ecol Appl 17 (5): 1267-1278.

Benton TG, Bryant DM, Cole L, Crick HQP. 2002. Linking agricultural practice to insect and bird populations: A historical study over three decades. J Appl Ecol 39 (4): 673-687.

Bibi F, Ali Z. 2013. Measurement of diversity indices of avian communities at Taunsa Barrage Wildlife Sanctuary, Pakistan. J Anim Plant Sci 23 (2): 469-474.

Brooks TM, Mittermeier RA, Mittermeier CG, Da Foncesa GAB, Rylands AB, Konstant WR, Flick P, Pilgrim J, Oldfield S, Magin G, HiltonTaylor C. 2002. Habitat loss and extinction in the hotspot of biodiversity. Conserv Biol 16 (4): 909-923.

Cooleman S, Bapeamoni F, Louette M, Lens L, Angenong'a U. 2015. Bird functional diversity in the Yangambi Biosphere Reserve, DR Congo. Bull. African Bird Club 22: 171-182.
Dinesh GK, Ramesh PT, Chitra N, Sugumaran MP. 2018. Ecology of birds and insects in organic and conventional (In-Organic) rice ecosystem. Int J Curr Microbiol App Sci 7 (4): 1769-1779.

Indonesian Bureau of Statistics 2017. Bontosikuyu regency in numbers. https://selayarkab.bps.go.id/publication/2018/09/26/754975a92117f73 247685ce8/kecamatan-bontosikuyu-dalam-angka-2018.html October 2018) [Indonesian].

Kim J, Chae J, Koo TH. 2007. Variation in bird diversity in relation to habitat size in the urban landscape of Seoul, South Korea. Acta Ornithol 42 (1): 39-44.

Li N, Yang W, Fang S, Li X, Liu Z, Leng X, An S. 2017. Dispersal of invasive Phytolacca americana seeds by birds in an urban garden in China. Integrative Zoology 12 (1): 26-31.

Marchese C. 2015. Biodiversity hotspots: A shortcut for a more complicated concept. Glob Ecol Conserv 3: 297-309.

Mas AH, Dietsch TV. 2004. Linking shade coffee certification to biodiversity conservation: butterflies and birds in Chiapas, Mexico. Ecol Appl 14 (3): 642-652.

Menhinick EF. 1964. A comparison of some species - individuals diversity indices applied to samples of field insects. Ecol 45: 859-61.

Mentil L, Battisti C, Carpaneto GM. 2018. The older the richer: Significant increase in breeding bird diversity along an age gradient of different coppiced woods. Web Ecology 18 (2): 143-151.

Mittermeier RA, Myers N, Thomsen JB, Da Fonseca GA, Olivieri S. 1998. Biodiversity hotspots and major tropical wilderness areas: Approaches to setting conservation priorities. Conserv Biol 12 (3): 516-520.

O'Connell TJ, Jackson LE, Brooks RP. 2000. Bird guilds as indicators of ecological condition in the central Appalachians. Ecol Appl 10 (6): 1706-21.

Philpott SM, Soong O, Lowenstein JH, Pulido AL, Lopez DT, Flynn DF, DeClerck F. 2009. Functional richness and ecosystem services: bird predation on anthropods in tropical agroecosystems. Ecol Appl 19 (7): 1858-67.

Pielou EC. 1966. The measurement of diversity in different types of biological collections. J Theor Biol 13: 131-44.

Sekercioglu CH. 2012. Bird functional diversity and ecosystem services in tropical forests, agroforests and agricultural areas. J Ornithol 153 (1): 153-161.

Smith, C Milligan MC, Johnson MD, Njoroge P. 2018. Bird community response to landscape and foliage anthropod variables in sun coffee of central Kenyan highlands. Glob Ecol Conserv. www.doi.org/10.1016/j.gecco.2018.e00378.

Sodhi NS, Koh LP, Prawiradilaga DM, Tinulele I, Putra DD, Tan THT. 2005. Land use and conservation value for forest birds in Central Sulawesi (Indonesia). Biol Conserv 122 (4): 547-558.

Spellerberg IF, Fedor PJ. 2003. A tribute to Claude Shannon (1916-2001) and a plea for more rigorous use of species richness, species diversity and the 'Shannon-Wiener' index. Global Ecol Biogeogr 12: 177-9.

Tanalgo KC, Pineda JAF, Agravante ME, Amerol ZM. 2015. Bird diversity and structure in different land-use types in Lowland SouthCentral Mindanao, Philippines. Trop Life Sci Res 26 (2): 85-103.

Tanner EP, Elmore RD, Davis CA, Fuhlendorf SD. 2017. Wintering bird responses to the presence of artificial surface water in a semi-arid rangeland. Wildlife Biology: wlb-00315.

van Ballen B, Rheindt FE, Eaton JE, Bricke NW. 2016. Birds of Indonesian Archipelago: Greater Sundas and Wallacea. Lynx Edicions, Barcelona.

Waltert M, Mardiastuti A, Mühlenberg M. 2004. Effects of land use on bird species richness in Sulawesi, Indonesia. Conserv Biol 18 (5): 1339-1346.

Waltert M, Mardiastuti A, Mühlenberg M. 2005. Effects of deforestation and forest modification on understorey birds in Central Sulawesi, Indonesia. Bird Conserv Int 15 (3): 257-273.

Yoccoz NG, Nichols JD, Boulinier T. 2001. Monitoring of biological diversity in space and time. Trends Ecol Evol 16 (8): 446-53. 